\title{
BERLIN RADIOCARBON MEASUREMENTS III
}

\author{
G. KOHL and H. M. MÜLLER
}

Deutsche Akademie der Wissenschaften zu Berlin, Deutsche Akademie der Landwirtschaftswissenschaften zu Berlin

The following list includes selected geologic and pollen dated samples measured since 1965. After moving to new laboratory quarters, we increased shielding to $470 \mathrm{~g} / \mathrm{cm}^{2}$ on all sides and $660 \mathrm{~g} / \mathrm{cm}^{2}$ at the top. Background of our Houtermans-Oeschger-type counters filled with $700 \mathrm{~mm} \mathrm{Hg}$ of acetylene is now:

\begin{tabular}{c} 
Counter \\
\hline I \\
IV \\
V
\end{tabular}

\begin{tabular}{ll} 
Volume \\
\hline 1.85 & 1 \\
2.23 & 1 \\
3.6 & 1
\end{tabular}

\begin{tabular}{c} 
Background \\
\hline $1.35 \mathrm{cpm}$ \\
$1.22 \mathrm{cpm}$ \\
$2.25 \mathrm{cpm}$
\end{tabular}

Influence of the filling pressure on the net background counting rate is in the range of $0.15 \mathrm{cpm}$ per $100 \mathrm{~mm} \mathrm{Hg}$ variation of the filling pressure. Pretreatment of samples with $5 \%$ hydrochloric acid and $5 \%$ sodium hydroxide is routine. This procedure is modified where sample size precludes alkali leaching. Acetylene is prepared by $\mathrm{SrC}_{2}$-method (Suess, 1954): sample $\rightarrow \mathrm{CO}_{2} \rightarrow\left(\mathrm{NH}_{4}\right)_{2} \mathrm{CO}_{3} \rightarrow \mathrm{SrCO}_{3} \rightarrow \mathrm{SrC}_{2} \rightarrow \mathrm{C}_{2} \mathrm{H}_{2}$. The reduction of $\mathrm{SrCO}_{3}$ to $\mathrm{SrC}_{2}$ is modified from Suess (1954). Strontium carbonate, after being heated to $500^{\circ} \mathrm{C}$ to remove traces of water and ammonia, is reduced to strontium carbide with a mixture of $60 \mathrm{~g}$ of $\mathrm{SrCO}_{3}$ to $40 \mathrm{~g}$ of $\mathrm{Mg}$-powder. After initiating the reaction by torch, the reduction is completed by heating the mixture to $900^{\circ} \mathrm{C}$ for $1 \mathrm{hr}$ in an electric furnace. Once the carbide is cooled, the mixture is passed through a screen to obtain satisfactory particle size. To generate acetylene, $10 \mathrm{cc}$ of tritium-free water are added dropwise to the carbide in 60 to $90 \mathrm{~min}$. Over-all yield is 90 to $95 \%$. In some cases acetylene was prepared by $\mathrm{Li}_{2} \mathrm{C}_{2}$-method. We find $\mathrm{Li}_{2} \mathrm{C}_{2}$ produced acetylene is not pure enough for counting in gas proportional counting equipment. Therefore, $\mathrm{Li}_{2} \mathrm{C}_{2}$ produced acetylene is converted with hydrogen into ethylene (Gey, 1964).

After two measurements in our proportional gas counting set, the acetylene samples were converted to benzene with vanadium pentoxide catalyst on silica gel at $20^{\circ} \mathrm{C}$ (Romanova and Tscherdintsev, pers. commun.). These benzene samples can be stored for a long time and controlled in a scintillation system as a check.

In agreement with international conventions, all calculations of dates are made with the radiocarbon half-life of $5570 \mathrm{yr}$. The modern standard is $95 \%$ of the NBS oxalic acid.

Extensive pollen analyses required the dating of stages of vegetational development. On the one hand, absolute dates are necessary for correlation of diagrams from the plains of East-Germany (GDR); on the other hand, they are necessary for the classification of important vegetational and climatic events in central Europe. Therefore, samples from 
TABle 1

\begin{tabular}{|c|c|c|c|c|}
\hline Location & & No. & $\begin{array}{c}\mathrm{C}^{14} \mathrm{yr} \\
\pm 100 \text { в.P. }\end{array}$ & \\
\hline \multirow[t]{4}{*}{ SEM* } & $\begin{array}{l}\text { Blänckbruch } \\
\text { Blänckbruch } \\
\text { Moosbruch Serrahn }\end{array}$ & $\begin{array}{l}\text { Bln-186 } \\
\text { Bln-187 } \\
\text { Bln-188 }\end{array}$ & $\begin{array}{l}438 \\
491 \\
586\end{array}$ & \multirow[t]{2}{*}{$\begin{array}{l}\text { Younger } \\
\text { Sub-Atlantic }\end{array}$} \\
\hline & $\begin{array}{l}\text { Moosbruch Serrahn } \\
\text { Moosbruch Serrahn }\end{array}$ & $\begin{array}{l}B \ln -189 \\
B \ln -190\end{array}$ & $\left.\begin{array}{l}805 \\
881\end{array}\right\}$ & \\
\hline & Moosbruch Zinow & Bln-196 & 1073 & \\
\hline & Moosbruch Zinow & Bln-197 & 1115 & $\begin{array}{l}\text { Older } \\
\text { Sub-Atlantic }\end{array}$ \\
\hline \multirow[t]{2}{*}{ NEL** } & Weisswasser & Bln- 663 & 1329 & \\
\hline & Weisswasser & Bln- 540 & 1234 & \\
\hline \multirow[t]{3}{*}{ SEM } & Moosbruch Zinow & Bln-198 & 1518 & \\
\hline & Moosbruch Zinow & $B \ln -199$ & 2516 & \\
\hline & Bixbeerenbruch & Bln-193 & 3824 & Sub-Boreal \\
\hline NEL & Kosel & $B \ln -486$ & 3899 & \\
\hline \multirow[t]{2}{*}{ SEM } & Bixbeerenbruch & Bln-194 & 4180 & \\
\hline & Bixbeerenbruch & Bln-195 & 4765 & Younger Atlantic \\
\hline \multirow[t]{3}{*}{ NEL } & Hohenleipisch I & $B \ln -488$ & 5056 & \\
\hline & $\begin{array}{l}\text { Hohenleipisch II } \\
\text { Hohenleipisch I }\end{array}$ & $\begin{array}{l}B \ln -538 \\
B \ln -487\end{array}$ & $\begin{array}{l}5578 \\
6090\end{array}$ & Older Atlantic \\
\hline & Hohenleipisch II & $B \ln -539$ & 11,283 & Ålleröd \\
\hline
\end{tabular}

* SEM $=$ SE Mecklenburg

* ${ }^{*} \mathrm{NEL}=\mathrm{NE}$ Lausitz 
Vegetational and historical events

uprooting in moist lowlands

Pinus curve rises

intensive uprooting phase

maximum of Fagus and Carpinus, just

before human influence

maximum of Fagus and Carpinus

beginning maximum of Fagus

end of Pinus max., increase of Fagus

$\int$ just before Sub-Boreal max. of Pinus,

i Fagus $5 \%$

$\int$ increase of Alnus, Betula, Quercus, decr.

$\{$ of Pinus

( beginning of a max. of Alnus and Quercus,

last max. of Corylus, beginning of sharp wet phase

increase of Fagus

max. of Pinus

end of Atlantic decrease of Ulmus

$\left\{\begin{array}{l}\text { just before a sharp increase of Alnus, } \\ \text { decrease of Atlantic max. of Tilia, Ulmus, beginning of a wet phase } \\ \text { and Corylus }\end{array}\right.$

decrease from 1. max. of Alnus

in midst of Ålleröd increase of Pinus

\section{Climatic events}

dry phase

wet phase

beginning of a wet phase

dry phase

beginning of a wet phase

dry phase

beginning of a dry phase 
SE Mecklenburg (SEM) and NE Oberlausitz (NEL) have been dated. Table I gives a summary of dates connected with vegetational-historical events and the climatic interpretation is shown. This table shows that the oldest dates were from NE Oberlausitz (NEL) and the youngest dates were from SE Mecklenburg( SEM). For the period between 5000 and 1100 yr B.P., dates of both areas agree approximately (Bln-488-195, 486-193, 663, 540, 197, 198). They indicate that vegetation-historical changes in E German (GDR) plain far from the shore occurred nearly synchronously.

Of great significance is the dating of late-glacial intensive expansion of pine in the Oberlausitz with 11,283 \pm 200 B.P. which shows good agreement with the Alleröd layer in NE Germany, dated by the "Eifeltuffe" (K. Steinberg, 1944; Straka and de Vries, 1956; H. Straka, 1965; Woldstedt, 1958). It appears that there were no large time differences between the expansion of wood species in NE Lausitz and in SE Mecklenburg during the Late-Glacial. Pollen dates of the decrease from Early Atlantic maximum of Alnus (Bln-487), of another maximum of Alnus, parallel to the Atlantic decrease of Ulmus (Bln-488, Bln-195), of the late Sub-Boreal maximum of Pinus (Bln-199, Bln-198) and of the Sub-Atlantic maximum of Fagus (Bln-190, 196, 197, 540, 663) are important for the chronology of vegetational development in the Holocene.

\section{SAMPLE DESCRIPTIONS}

$438 \pm 120$

\section{Bln-186. Blänkbruch}

A.D. 1512

Sphagnum peat from Blänckbruch bog near Carpin, Kreis Neustrelitz (53 $22^{\prime} \mathrm{N}$ Lat, $13^{\circ} 15^{\prime} \mathrm{E}$ Long); depth 0.35 to $0.40 \mathrm{~m}$. Coll. and subm. by H. M. Müller, Inst. für Waldkunde, Eberswalde. Comment: Pollen Horizon X (Firbas-system); no $\mathrm{NaOH}$ pretreatment.

\section{Bln-187. Blänckbruch}

A.D. 1459

$$
491 \pm 100
$$

Humified bog-peat from Blänckbruch bog; depth 0.45 to $0.50 \mathrm{~m}$. Pollen Horizon X (Firbas); no NaOH pretreatment.

\section{Serrahn series}

Peat samples from Serrahn bog, Kreis Neustrelitz $\left(53^{\circ} 40^{\prime} \mathrm{N}\right.$ Lat, $12^{\circ} 20^{\prime}$ E Long). Samples taken by excavation. Coll. and subm. 1963 by H. M. Müller.

\section{Bln-188. Mooshruch Serrahn, $0.22 \mathrm{~m}$}

Moderately to highly humified Sphagnum peat from above $0.5 \mathrm{~cm}$ thick layer at $0.22 \mathrm{~m}$ depth. Pollen Horizon X (Firbas); no $\mathrm{NaOH}$ pretreatment.

Bln-189. Mooshruch Serrahn, $0.42 \mathrm{~m}$ A.D. 1145 $805 \pm 100$

Highly humified Eriophorum and Sphagnum peat. Pollen Horizon $\mathrm{X}$ (Firbas). 
Bln-190. Moosbruch Serrahn, $0.50 \mathrm{~m}$

$881 \pm 100$

Highly humified Eriophorum and Sphagnum peat. Pollen Horizon $\mathrm{X}$ (Firbas).

\section{Zinow series}

Samples from Zinow bog near Thurow, Kreis Neustrelitz. Samples collected by excavation. Bog was drained, surface destroyed by fire in 1952. Peat near surface strongly humified. Coll. and subm. 1963 by H. M. Müller.

Bln-196. Zinow, 0.20 to $0.25 \mathrm{~m}$

$$
1073 \pm 100
$$

Moderately humified Sphagnum peat, 0.20 to $0.25 \mathrm{~m}$ below surface, penetrated by modern roots. Comment: end of Pollen Horizon IX (Firbas).

\section{Bln-197. Zinow, 0.30 to $0.35 \mathrm{~m}$}

$1115 \pm 100$

Moderately humified Sphagnum and Eriophorum peat, penetrated by modern roots. Pollen Horizon IX (Firbas).

\section{BIn-198. Zinow, 0.45 to $0.50 \mathrm{~m}$}

$1518 \pm 100$

Moderately humified Sphagnum peat, penetrated by modern roots. Pollen Horizon IX (Firbas).

Bln-199. Zinow, 0.60 to $0.65 \mathrm{~m}$

$$
2516 \pm 100
$$

566 B.c.

Moderately humified Sphagnum peat, penetrated by roots. Pollen Horizon VIII (Firbas).

\section{Bixbeerenbruch series}

Peat samples from Bixbeerenbruch bog near Serrahn, Kreis Neustrelitz. Samples collected by excavation. Coll. and subm. 1963 by H. M. Müller.

\section{Bln-192. Bixbeerenbruch, 0.30 to $0.35 \mathrm{~m}$}

$3027 \pm 100$

Highly humified stabilized peat, penetrated by modern roots. Pollen Zone VIII (Firbas). Increase of Fagus.

\section{Bln-193. Bixbeerenbruch, 0.35 to $0.40 \mathrm{~m}$}

$3824 \pm 100$

Highly humified strong stabilized peat, penetrated by modern roots. Pollen Horizon VIII (Firbas). Increase of Betula, Alnus, Quercus, decrease of Pinus.

\section{Bln-194. Bixbeerenbruch, 0.45 to $0.50 \mathrm{~m}$}

Highly humified strong stabilized peat, penetrated by modern roots. End of Pollen Horizon VIII (Firbas), 4th Corylus maximum. 
Bln-195. Bixbeerenbruch, $0.60 \mathrm{~m}$

Highly humified peat, slightly wet, somewhat penetrated by modern roots. Pollen Horizon VII (Firbas).

\section{Bln-663. Weisswasser}

$1329 \pm 100$

A.D. 621

Peat from brown coal open mine "Frieden" Profile II $\left(51^{\circ} 30^{\prime} \mathrm{N}\right.$ Lat, $14^{\circ} 30^{\prime} \mathrm{E}$ Long) at depth $0.55 \mathrm{~m}$. Peat contains much birch wood. Coll. 1966 by K. H. Grosser, Inst. für Iandesforschung und Naturschutz, Halle, Zweigstelle Potsdam. Subm. by H. M. Müller. Comment: Fagus maximum of older Sub-Atlantic.

$$
1234 \pm 100
$$

BIn-540. Weisswasser

$$
\text { A.D. } 716
$$

Cellulose, isolated from peat of Bln-663 with "Schweizers" reagent.

\section{Bln-486. Kosel}

$$
\begin{aligned}
& 3899 \pm 100 \\
& 1949 \text { B.C. }
\end{aligned}
$$

Half-bog raw humus from Picea-Pinus forest from Kosel Heideanger, Bezirk Cottbus, Lausitz. Depth 0.20 to $0.23 \mathrm{~m}$. Coll. and subm. by $\mathrm{H}$. M. Müller. Comment: decrease of Corylus maximum, increase to Fagus maximum of Sub-boreal, Pollen Zone VIII (Firbas).

\section{Hohenleipisch series}

Samples from 2 locations from bog near Hohenleipisch, Bezirk Cottbus, Lausitz ( $13^{\circ} 35^{\prime} \mathrm{E}$ Long, $51^{\circ} 30^{\prime} \mathrm{N}$ Lat). Profile I: below meadow, $0.65 \mathrm{~m}$ peat above $0.75 \mathrm{~m}$ mud and underlying sands. Coll. and subm. 1965 by H. M. Müller. No NaOH pretreatment. Profile II: below meadow $1.20 \mathrm{~m}$ peat above sands. Coll. and subm. 1966 by H. M. Müller.

\section{Bln-488. Hohenleipisch I}

$5056 \pm 100$

Peat from depth 0.32 to $0.35 \mathrm{~m}$. Decrease of Corylus maximum of older Atlantic. Pollen Zone VIII (Firbas).

\section{Bln-487. Hohenleipisch I}

$6090 \pm 100$

Peat from charred layer 0.50 to $0.55 \mathrm{~m}$ deep. Older Atlantic, Pollen Zone VII/VI (Firbas).

\section{BIn-538. Hohenleipisch II}

Highly humified sedge and Hypnum moss peat, depth $0.60 \mathrm{~m}$. Pollen analysis shows: Picea $0.9 \%$, Pinus $20 \%$, Betula $43 \%$, Alnus $30 \%$, Quercus $4.6 \%$, Tilia $0.9 \%$, Ulmus $0.9 \%$, Fraxinus $0.6 \%$, Corylus $8 \%$, Salix, $1.6 \%$, non-tree pollen $3 \%$. Comment: 1st half of Atlantic, Pollen Zone VI/VII (Firbas). 


\section{BIn-539. Hohenleipisch II}

$11,283 \pm 200$

9333 в.c.

Highly humified peat, depth 0.98 to $1.03 \mathrm{~m}$. Pollen analysis shows: Betula, $56 \%$, Pinus $41 \%$, Alnus $3.7 \%$, Corylus $0.3 \%$, Salix $1 \%$, non-tree pollen $44 \%$. Comment: Pollen Zone II (Firbas).

General Comment: dates of vegetational change agree well with those from other regions of Central Europe. Study of numerous pollen profiles permits inferences about paleoclimatic fluctuations in the Holocene. Repeated change in vegetational structure indicates fluctuations of moisture from Pre-Boreal to Sub-Atlantic time. In NE Germany the number of moist and dry phases appears greater than in SE Germany. Absolute dating of changes of moisture availability in different regions indicate a relationship to changes of sea level.

Date lists:

\section{REFERENCFS}

Berlin I Kohl and Quitta, 1964

Berlin II Kohl and Quitta, 1966

Gev, M. A., 1964, Dissertation, Bergakademie Claustal.

Steinberg, K., 1944, Zur spät-und nacheiszeitlichen Vegetationsgeschichte des Untereichsfeldes: Hercynia, v. 3 .

Straka, Herbert, 1956, Pollenanalytische Datierungen zum Alter des Maar-Vulkanismus der Eifel: Int. Quaternary Assoc., 4th Cong., Rome-Pisa, Actes I, p. 184-188.

Straka, H. and de Vries, Hl., 1956, Eine Radiokarbon-Datierung zum Alter der Eifelmaare: Naturwiss, v. 43.

Suess, H. E., 1954, Natural radiocarbon measurements by acetylene counting: Science, v. 120 , p. 5-7.

Woldstedt, Paul, 1958, Das Eiszeitalter: Ed. 2, 438 p., Stuttgart. 